\title{
Studies on Induced Tetraploid in Four Diverse Cultivars of Pea (Pisum sativum L.)
}

\author{
Mercy kutty V. C. and H. Kumar \\ Department of Genetics and Plant Breeding, Banaras Hindu \\ University, Varanasi, India
}

Received January 12, 1981

Although chromosome doubling and its manifestation on cytomorphology have been well documented in a wide range of plants, the pea, an important grain legume, has received little attention so far. A few earlier studies are preliminary (D'jačuk and Cheredeeva 1974, D'jacuk and Popova 1967, Ono 1940a, b, c and Serebrovskaya 1974) and the method available for chromosome doubling is not efficient. Induction of polyploidy, though associated with reduced fertility, has assumed great significance as chromosome doubling is usually associated with the changes in the morphological and physiological behaviour, apart from chromosomal instability owing to cytological irregularities. The present paper deals with the induction of colchiploidy and certain aspects of cytomorphological characterisation in four diverse cultivars of pea (Pisum sativum L.).

\section{Materials and methods}

Four diverse pea cultivars, namely, T 163 (indigenous), $68 \mathrm{C}$ (W. Germany), 5064-S (Sweden-a selection from the line 5064) and P. I. 280064 (Canada) having varying levels of protein were used for the present study. Seedlings with $1.5-2 \mathrm{~cm}$ long shoot, raised in sterilized saw-dust at room temperature $\left(25-29^{\circ} \mathrm{C}\right)$, were treated with aqueous colchicine solution. Growing seedlings were put up side down supported by the thread net-work over a petri-dish containing colchicine solution in such a way that only the shoot apex should remain in the solution. After the treatment, seedlings were washed for one $\mathrm{hr}$ and transplanted in the field.

Tetraploids were analysed for certain morphological traits such as stomata size and frequency, size of flower, pod and seed etc. Pollen sterility was analysed from their stainability with $2 \%$ iodine solution while ovule sterility was counted on the basis of full and aborted seeds in a pod. PMC's were collected in acetic-alcohol fixative (1:3) and squeezed in 2 per cent aceto-carmine for detailed cytological studies. Cytomorphological studies were performed on ten randomly selected plants in both tetraploids and diploids of each cultivars and data were statistically analysed.

\section{Results and discussion}

The mode of treatment and the optimum concentration of colchicine in inducing tetraploid varies with the type of plants and plant parts treated. Of the several methosd tried at this laboratory to induce colchiploidy in pea (Data unpublished), 
seedling treatment with low concentration of colchicine $(0.025 \%)$ for 4 hrs was found to be most effective (Table 1). With the increase in concentration of colchicine and treatment duration seedling lethality increased. D'jačuk and Popova (1967) and Serebrovskaya (1974) also favoured low concentration but former found seed treatment most effective in getting trteaploids in pea. The sensitivity of the material to colchicine, as judged from the viable tetraploid scored, appeared to be genotype specific and related to the seed index (Table 1). The cultivars, T 163 (indigenous) and $68 \mathrm{C}$ (W. Germany) having high seed index, showed more response to colchicine as compared to the cultivars, 5064-S and P. I. 280064 with low seed index. D'jačuk and Popova (1967) also found large seeded varieties to be more sensitive to colchicine $(0.001-0.005 \%)$ than small seeded one in peas.

Table 1. Chromosome doubling by colchicine treatment of seedlings in four cultivars of pea

\begin{tabular}{|c|c|c|c|c|c|c|}
\hline Cultivars & $\begin{array}{c}\text { Colchicine } \\
\text { concentra- } \\
\text { tion } \\
(\%)\end{array}$ & $\begin{array}{l}\text { Number of } \\
\text { seedlings } \\
\text { treated }\end{array}$ & $\begin{array}{l}\text { Treat- } \\
\text { ment } \\
\text { dura- } \\
\text { tion } \\
\text { (hr) }\end{array}$ & $\begin{array}{l}\text { Survival of } \\
\text { seedlings at } \\
\text { maturity } \\
(\%)\end{array}$ & $\begin{array}{l}\text { Viable tetra- } \\
\text { ploid scored } \\
\text { (per cent over } \\
\text { seedlings } \\
\text { treated) }\end{array}$ & $\begin{array}{l}\text { Seed-index (g) } \\
\text { (25-seed } \\
\text { weight) }\end{array}$ \\
\hline T 163 & 0.025 & 200 & 4 & 47.5 & 15 & 5.40 \\
\hline (Indigenous) & 0.025 & 200 & 8 & 25.0 & 10 & \\
\hline \multirow[t]{2}{*}{, } & 0.050 & 200 & 4 & 28.0 & 11 & \\
\hline & 0.050 & 200 & 8 & 12.5 & 7 & \\
\hline \multirow[t]{2}{*}{, } & 0.100 & 200 & 4 & 14.0 & 8 & \\
\hline & 0.100 & 200 & 8 & 8.0 & 4 & \\
\hline \multirow[t]{2}{*}{ ", } & 0.150 & 200 & 4 & 10.5 & 7 & \\
\hline & 0.150 & 200 & 8 & 3.0 & 1 & \\
\hline $\begin{array}{l}68 \mathrm{C} \\
\text { (W. Germany) }\end{array}$ & 0.025 & 100 & 4 & 49.0 & 11 & 5.68 \\
\hline $\begin{array}{l}5064-S \\
\text { (Sweden) }\end{array}$ & 0.025 & 100 & 4 & 37.0 & 9 & 3.68 \\
\hline $\begin{array}{l}\text { P. I. } 280064 \\
\text { (Canada) }\end{array}$ & 0.025 & 100 & 4 & 36.0 & 9 & 2.92 \\
\hline
\end{tabular}

Data with regard to certain morphological traits are presented in Table 2. Tetraploids differed significantly from diploid and also among themselves for all the traits and were characterised by the increase in size of stomata, pollen grain, flower, pod width, seed index and delayed flowering and maturity by 10-15 days as compared to the control. Further, they were also characterised by slow growth, thick and dark green leaves, reduced stomata frequency, internode and pod length and seed setting. Similar observations were also recored in pea tetraploids by others (Bijačuk and Popova 1967, Ono 1940b and Serebrovskaya 1974). However, the magne of change was noted to be genotype specific. The decrease in stomata frequency in tetraploids of T 163 and 5064-S were about six and three times than that of their respective diploids, respectively (Table 2 ).

Pollen grains in tetraptoid were more or less triangular shape as compared to the ovat in thiphoid (Fig. 1) and behaved smilarly in all the four cultivars. The change in the shape of pollen grain due to chromosome doubling was also noted in 


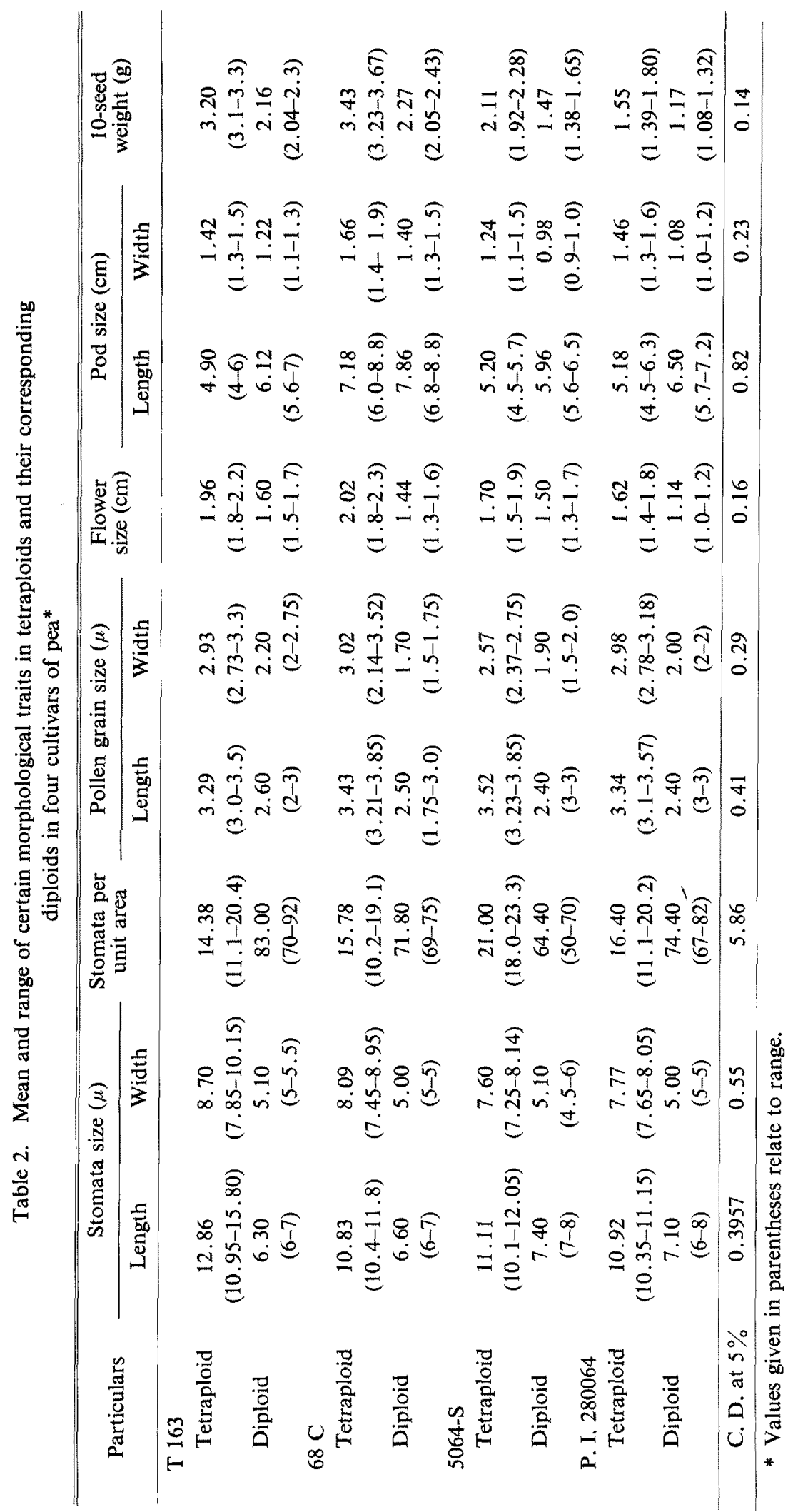




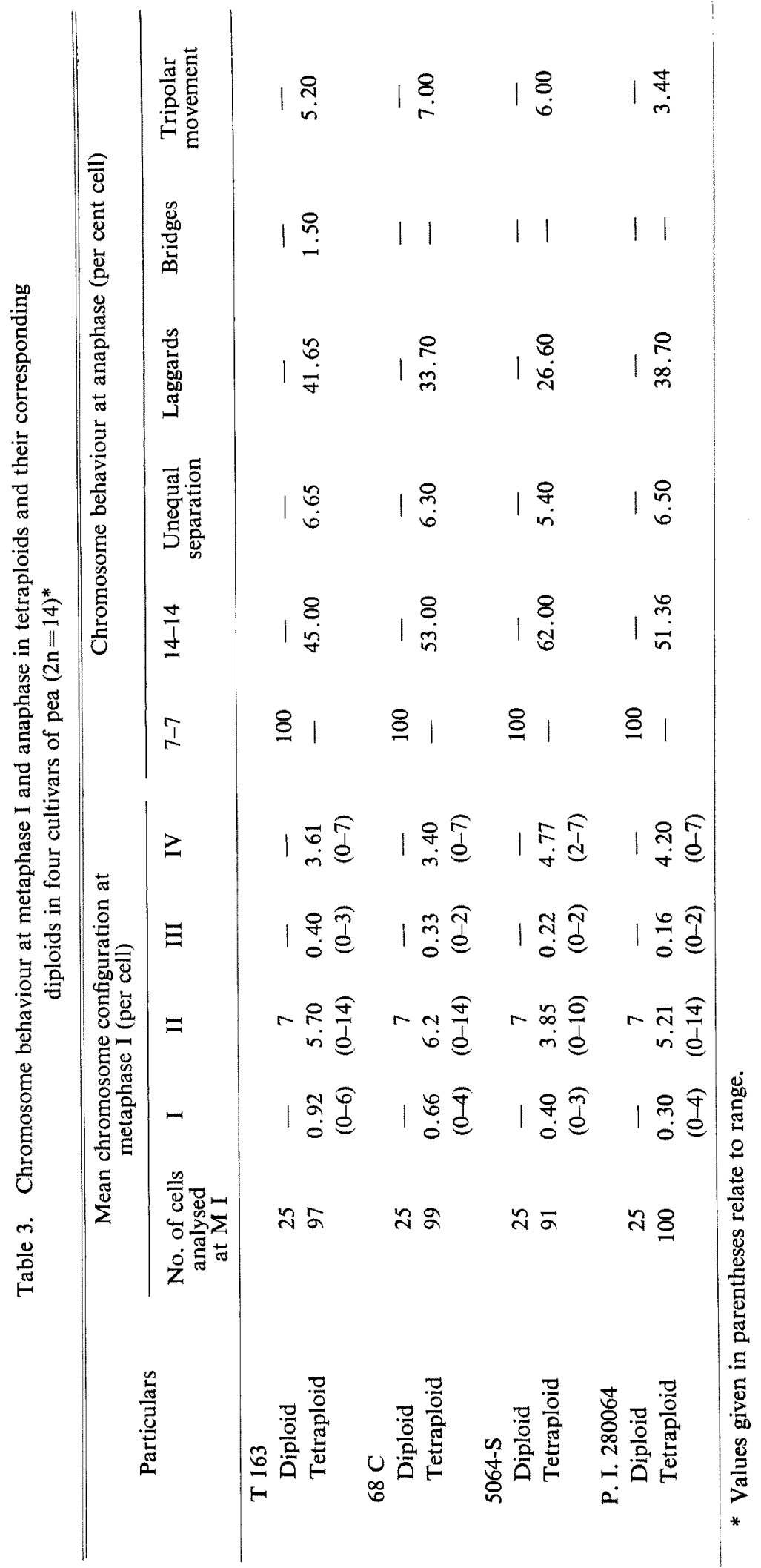


Vicia faba (Poulsen and Martin 1977) and red clover (Eskilsson 1971).

Chromosome behaviour (Figs. 2-9) at tetraploid level also varied with the cultivars (Table 3) like morphological traits. The T 163 tetraploid had more univalent (0.92) and trivalent $(0.40)$ per cell as compared to the cultivar 5064-S which had just half of the former (Table 3) and consequently more abnormal PMC's were observed in the tetraploid of T $163(55 \%)$ than the 5064-S (38\%). The quadrivalent frequency per cell was more in the tetraploid of 5064-S (4.77) and P. I. 280064 (4.20) than the

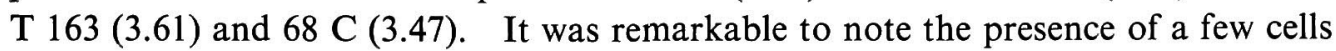
with 14 bivalents in tetraploids of all the cultivars except 5064-S. Bivalents per cell
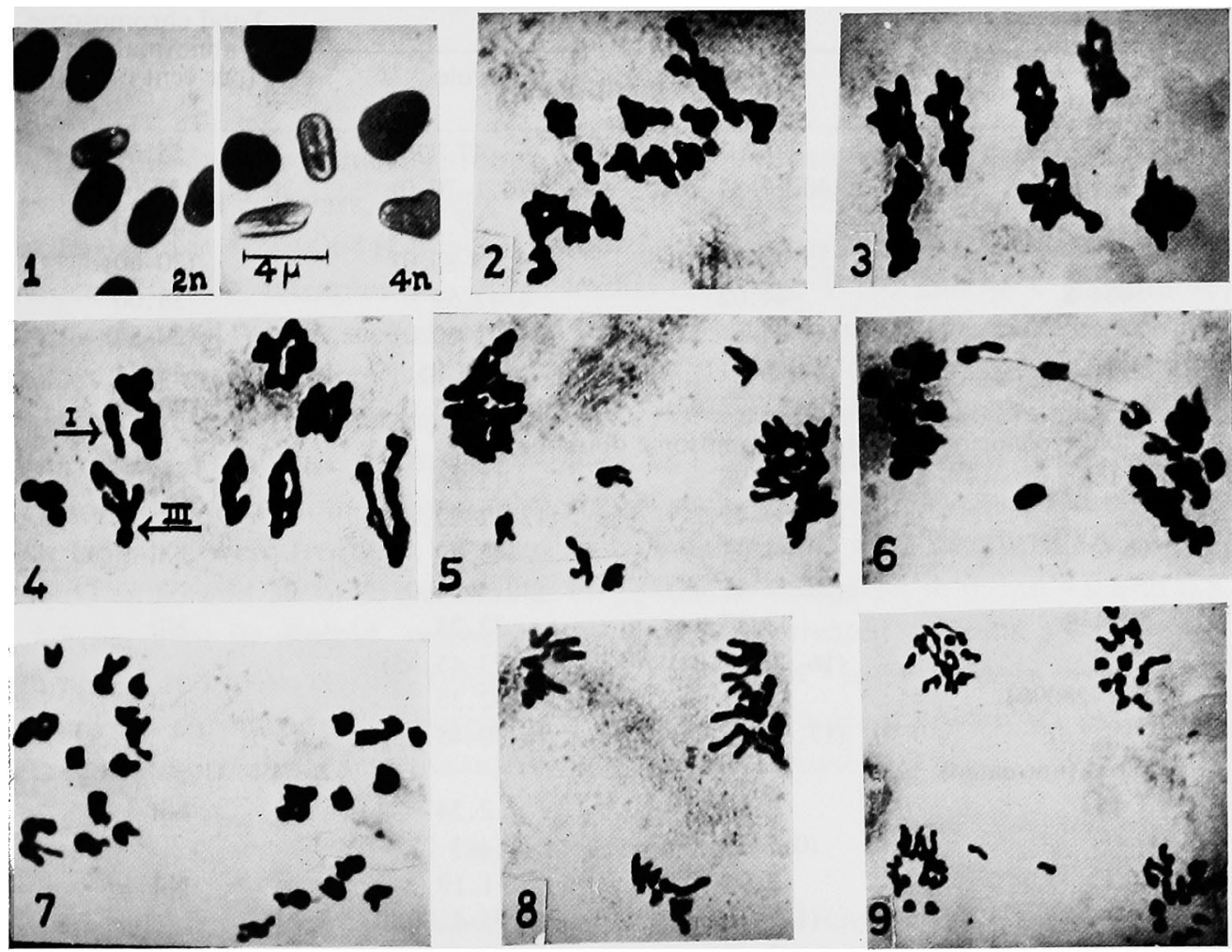

Figs. 1-9. Pollen grain and chromosome behaviour in tetraploid and diploid in pea. 1, pollen grains in diploid and tetraploid. 2, tetraploid, 14 II. 3, tetraploid, 7 IV. 4, tetraploid, 4 IV+ $1 \mathrm{III}+4 \mathrm{II}+1 \mathrm{I}$. 5, anaphase I, 5 laggards. 6, anaphase I, 1 laggard and bridge. 7, anaphase I, unequal separation, 15-13. 8, tripolar movement. 9, anaphase II, 2 laggards.

ranged from 3.85 to 6.2 ; minimum and maximum were in tetraploids of the cultivars 5064-S (3.85) and $68 \mathrm{C}(6.2)$, respectively. Among the chromosomal abnormalities, laggards were most frequent ranging from 26.6 (5064-S) to 41.65 (T 163) per cent cells in tetraploids. Tripolar movements was maximum in $68 \mathrm{C}$ while bridges at anaphase I and II were observed only in T 163 ( 1.5 per cent cells). Unequal separation at anaphase I was more or less similar in the tetraploids and ranged from 5.4 to 6.65 per cent cells; other abnormalities such as clumping and stickiness of chromosomes etc. were not observed in the present study.

Besides, chromosome doubling had significant but variable effects on fertility 
of tetraploids (Table 4). Pollen and ovule sterility behaved similarly in the tetraploid of four cultivars and ranged from 33-85 and 24-80 per cent, respectively. However, on an average 5064-S tetraploid had low pollen (44.02\%) and ovule $(47.59 \%)$ sterility as compared to others (Table 4$)$. Total chromosome abnormalities did not show varietal difference.

Table 4. Mean and range of pollen, ovule sterility and total chromosome abnormalities in tetraploids and their corresponding diploids (treated and untreated) in four cultivars of pea*

\begin{tabular}{|c|c|c|c|}
\hline \multirow{2}{*}{$\begin{array}{l}\text { Treatments } \\
\text { Tetraploids }\end{array}$} & \multicolumn{2}{|c|}{ Sterility $(\%)$} & \multirow{2}{*}{$\begin{array}{l}\text { Total chromosome } \\
\text { abnormalities } \\
\text { (per cent of cell) }\end{array}$} \\
\hline & Pollen & Ovule & \\
\hline T 163 & $\begin{array}{c}62.23 \\
(40.17-84.78)\end{array}$ & $\begin{array}{c}47.72 \\
(24.1-70.0)\end{array}$ & $\begin{array}{c}55.00 \\
(50-60)\end{array}$ \\
\hline $68 \mathrm{C}$ & $\begin{array}{c}54.82 \\
(35.98-79.65)\end{array}$ & $\begin{array}{c}57.33 \\
(28.66-80.0)\end{array}$ & $\begin{array}{c}47.00 \\
(30-60)\end{array}$ \\
\hline $5064-S$ & $\begin{array}{c}44.02 \\
(33.34-61.22)\end{array}$ & $\begin{array}{c}47.59 \\
(34.41-60.0)\end{array}$ & $\begin{array}{c}38.00 \\
(20-50)\end{array}$ \\
\hline P. I. 280064 & $\begin{array}{c}66.11 \\
(58.21-72.03)\end{array}$ & $\begin{array}{c}60.85 \\
(50.0-75.0)\end{array}$ & $\begin{array}{c}48.44 \\
(40-60)\end{array}$ \\
\hline \multicolumn{4}{|c|}{ Diploid (colchicine treated-no chromosome doubling) } \\
\hline T 163 & $\begin{array}{c}29.96 \\
(16.09-41.21)\end{array}$ & $\begin{array}{c}15.66 \\
(12.11-22.62)\end{array}$ & Nil \\
\hline $68 \mathrm{C}$ & $\begin{array}{c}34.03 \\
(28.57-41.04)\end{array}$ & $\begin{array}{c}45.89 \\
(30.4-56.0)\end{array}$ & Nil \\
\hline $5064-S$ & $\begin{array}{c}23.47 \\
(16.24-37.84)\end{array}$ & $\begin{array}{c}32.23 \\
(18.73-45.45)\end{array}$ & Nil \\
\hline P. I. 280064 & $\begin{array}{c}37.49 \\
(17.58-56.25)\end{array}$ & $\begin{array}{c}32.35 \\
(6.70-45.45)\end{array}$ & Nil \\
\hline \multicolumn{4}{|c|}{ Diploid (untreated) } \\
\hline T 163 & $\begin{array}{c}2.38 \\
(0.7-3.7)\end{array}$ & $\begin{array}{c}2.34 \\
(1.4-3.2)\end{array}$ & Nil \\
\hline $68 \mathrm{C}$ & $\begin{array}{c}2.94 \\
(1.5-4.0)\end{array}$ & $\begin{array}{c}1.19 \\
(0.75-1.90)\end{array}$ & Nil \\
\hline $5064-\mathrm{S}$ & $\begin{array}{c}3.40 \\
(1.8-5.0)\end{array}$ & $\begin{array}{c}1.86 \\
(0.81-3.1)\end{array}$ & Nil \\
\hline P. I. 280064 & $\begin{array}{c}3.54 \\
(2.2-4.1) \\
\end{array}$ & $\begin{array}{c}1.80 \\
(0.50-3.1) \\
\end{array}$ & Nil \\
\hline C. D. at $5 \%$ & 7.90 & 9.11 & NS \\
\hline
\end{tabular}

* Values given in parentheses relate to range.

Lack of significant correlation between sterility and chromosome abnormalities in none of the cultivars suggested that the reduction in fertility of tetraploids was probably due to some other factors, besides chromosomal imbalance resulted by chromosomal duplication. In present case, a remarkable magnitude of pollen and ovule sterility ranging from 16.09 to 56.25 and 6.70 to 56.00 per cent, respectively, were noted in colchicine treated plant which had neither chromosome doubling and nor chromosomal abnormalities as compared to both diploids (untreated) and 
tetraploids (Table 4). Similar types of observations were also noted by Rao (1795) and Pillai (1978), among others. Dynansagar and Sudhakaran (1970), Magoon et al. (1957-58), Pillai (1978) and Shambulingappa et al. (1970) suggested that in addition to meiotic abnormalities, some genetic, physiological and environmental factors appeared to be implicated in the reduction of fertility in tetraploid. Parthasarthy (1953) held the view that chromosome doubling might upset the balance of polygenes and/or modifying genes controlling sterility and, hence resulting in no correlation between sterility and chromosome abnormalities. The results, thus, suggested the possible role of per se effects of colchicine, besides chromosome doubling, in reducing fertility in tetraploids.

\section{Summary}

Tetraploids were induced through colchicine treatment of $1.5-2.0 \mathrm{~cm}$ long seedlings in four pea cultivars, namely, T 163 (indigenous), $68 \mathrm{C}$ (W. Germany), 5064-S (Sweden) and P. I. 280064 (Canada). Four hours treatment with $0.025 \%$ colchicine produced $10-15 \%$ tetraploids. Large seeded cultivars, T 163 and $68 \mathrm{C}$ gave more tetraploids than small seeded ones. Tetraploids showed siginficant varietal differences and were characterised by large stomata, flowers, seeds and pod width and delayed flowering and maturity by 10-15 days while stomata frequency and pod length showed reduction. Both bivalents and quadrivalents were prominent in tetraploid. Chromosome abnormalities were more in T 163 tetraploid (55 per cent cell); laggards were frequent. Pollen and ovule sterility were parallel and ranged from 33 to 85 and 24 to 80 per cent in tetraploid as compared to 0.7 to 5.0 and 0.5 to 3.2 per cent in diploid, respectively. Colchicine treated diploids also showed high pollen and ovule sterility ranging from 16 to 56 and 7 to 56 per cent, respectively but had no chromosome abnormality. The possible role of colchicine and chromosomal abnormalities in reducing fertility were discussed.

\section{Acknowledgements}

We wish to express our sincere thanks to Dr. W. Gottschalk (W. Germany), Dr. S. Blixt (Sweden) and Dr. A. E. Slinkard (Canada) for making available the materials.

\section{References}

D'jačuk, P. A. and Cheredeeva, V.S. 1974. 'Polyploidy in the genus Pisum'. In Teoretich. i. praktich probl. poliploidii. Moscow, USSR, Nauka (1974): 185-213.

_ and Popova, I. S. 1967. 'Polyploidy in peas'. Genetica (Moskva) 1: 13-24.

Dynansagar, V. R. and Sudhakaran, I. V. 1970. Induced tetraploidy in Vicia rosea. Linn. Cytologia 35: 227-241.

Eskilsson, L. 1971. Studies on the use of induced autopolyploidy in the breeding of red clover. Part 1. The relation between meiosis and pollen fertility in tetraploid red clover. $Z$. Pflanzenzüchtg. 66 : 221-234.

Magoon, M. L., Cooper, D. C. and Hougas, R. W. 1957-58. Induced polyploids of Solanum and their crossability with $S$. tuberosum. Bot. Gaz. 119: 224-231.

Ono, T. 1940a. Experiments on chromosome doubling by means of acenaphthene treatment. 
Bot. and Zool. 8 : $39-46$.

- 1940b. The effects of polyploidy upon morphological and physiological characters in Pisum sativum. Bot. and Zool. 8: 1265-1274.

- 1940c. The production of colchicine induced polyploids of the pea. Bot. and Zool. 8: 3946.

Parthasarathy, W. 1953. Studies in the fertility of autotetraploid of Brassica compestris var. toria. Euphytica 2: 25-32.

Pillai, R. S. N. 1978. Cytogenetic studies in safflower (Carthamus tinctorius L.). Ph. D. Thesis (unpl.). Banaras Hindu University, Varanasi, India.

Poulsen, M. H. and Martin, A. 1977. A reproductive tetraploid in Vicia faba L. Hereditas 87: 123-126.

Rao, P. N. 1975. Male sterility in Chionachne koenigi. Maydica 20: 197-202.

Serebrovskaya, A. A. 1974. The effects of colchicine on peas. In Teoretich. i. praktich probl. poliploidii. Moscow, USSR, Nauka (1974): 214-218.

Shambulengappa, K. G., Chennaveeraiah, M. S. and Patel, S. R. 1965. Artificial induction of polyploidy in Trigonella foessum-glaceum. Cytologia 30: 205-212. 